\title{
CONTENT OF AMINO ACIDS IN THE RUMEN OF COWS UNDER CONDITIONS OF FEEDING HIGH-PROTEIN EXTRUDED SUPPLEMENTS
}

\author{
I. V. Nevostruyeva \\ iryna.nevostruyeva@gmail.com
}

Institute of Animal Biology NAAS,

38 V. Stus str, Lviv 79034, Ukraine

Increase in the quantity of undegradable in the rumen proteins in the diet of cows of experimental group caused by extruding of high-protein supplements was accompanied by the change of total and free amino acids in ruminal contents. The amount of total amino acids in the rumen of cows of experimental group during all experiments was greater by $9.8-10.8 \%$, which was mostly caused by the increase of the amount of essential amino acids $(P<0.05-0.01)$. Irrespective of the source of protected proteins during all experiments in the rumen of cows in experimental group, the increase of the concentration of lysine, arginine, methionine, proline and cystine was determined $(P<0.05-0.01)$, while feeding rapeseed and soybean meal - increase of the concentration of valine, threonine and phenylalanine as well, and while feeding sunflower cake - increase of the concentration of leucine. Among nonessential amino acids in the rumen of cows in the experimental groups, the amount of asparaginic acid, serine, and alanine was increasing $(P<0.05-0.01)$.

As opposed to total amino acids, concentration of free amino acids in the ruminal contents of cows of experimental group was smaller by $14.8-18.0 \%(P<0.05)$ compared to animals of control group that was mainly caused by decrease of the concentration of essential amino acids - histidine, methionine, and leucine. Considering nonessential amino acids, at the same time, concentration of glutaminic acid and asparaginic acid, glycine, proline, serine, and tyrosine has decreased $(P<0.05-0.01)$. These data are the evidence of decrease of degradability of essential amino acids and of increase of their intake into bowel, and uptake by cows.

Keywords: COWS, RUMEN CONTENTS, AMINO ACIDS, RAPESEED MEAL, SOYBEAN MEAL, SUNFLOWER CAKE, EXTRUDED FODDER, LACTATION

\section{ВМІСТ АМІНОКИСЛОТ У РУБЦІ КОРІВ ЗА ЗГОДОВУВАННЯ ВИСОКОБІЛКОВИХ ЕКСТРУДОВАНИХ ДОБАВОК}

\author{
I. В. Невоструєва \\ iryna nevostruyeva@gmail.com
}

Інститут біології тварин НААН,

вул. В. Стуса, 38, м. Львів, 79034, Україна

Збільщення кількості нерозщеплюваного в рубці протеїну - складового компонента раціону корів дослідних груп за рахунок екструдування високобілкових добавок супроводжувалось змінами у вмісті рубия концентрації загальних і вільних амінокислот. Сума загальних амінокислот у рубиі корів дослідних груп, порівняно з контрольними, у всіх дослідах була на 9,8-10,8\% більшою переважно за рахунок збільшення кількості незамінних амінокислот $(P<0,05-0,01)$. Незалежно від джерела захищеного протё̈ну, у всіх дослідах у рубці корів дослідних груп виявлено збільшення концентрації лізину, аргініну, метіоніну, проліну і ичстину $(P<0,05-0,01)$, при згодовуванні ріпакового і соєвого шротів - також концентрації валіну, треоніну та фенілаланіну, а при згодовуванні соняшникової макухи - концентраиії лейцину. Серед замінних амінокислот у рубці корів дослідних груп при изьому збільиувалась кількість аспарагінової кислоти, серину, аланіну $(P<0,05-0,01)$.

На відміну від загальних амінокислот, концентрація вільних амінокислот у вмісті рубия корів досліднх груп була на 14,8-18,0\% меншою $(P<0,05)$, ніж у корів контрольної групи, в основному внаслідок зменшення концентрації незамінних амінокислот гістидину, метіоніну, лейцину. Із замінних амінокислот при цььому зменшилася концентрація глютамінової і аспарагінової кислот, гліцину, проліну, серину, тирозину $(P<0,05-0,01)$. Ці дані свідчать про зменшення деградації незамінних амінокислот в рубці та збільшення їх надходження в кишківник $і$ засвоєння в організмі. 
Ключові слова: КОРОВИ, УМІСТ РУБЦЯ, АМІНОКИСЛОТИ, РІПАКОВИЙ ШРОТ, СОЄВИЙ ШРОТ, СОНЯШНИКОВА МАКУХА, ЕКСТРУДОВАНІ КОРМИ, ЛАКТАЦІЯ

\title{
СОДЕРЖАНИЕ АМИНОКИСЛОТ В РУБЦЕ КОРОВ ПРИ СКАРМЛИВАНИИ ВЫСОКОБЕЛКОВЫХ ЭКСТРУДИРОВАННЫХ ДОБАВОК
}

\author{
И. В. Невоструева \\ irynanevostruyeva@gmail.com
}

Институт биологии животных НААН,

ул. В. Стуса, 38, г. Львов, 79034, Украина

Увеличение количества нерасшепляемого в рубче протеина в рационе коров опытных групп за счет экструдирования высокобелковых добавок сопровождалось изменениями в содержсимом рубиа конценттрации общих и свободных аминокислот. Сумма общих аминокислот в рубце коров опьтных групп, по сравнению с контрольными, во всех опытах была на 9,8-10,8\% больше, в основном за счет увеличения количества незаменимых аминокислот $(P<0,05-0,01)$. Независимо от источника зашищенного протеина, во всех опьтах в рубче коров опьтныхх групп обнаружено увеличение концентрации лизина, аргинина, метионина, пролина и цүистина $(P<0,05-0,01)$, при скармливании рапсового и соевого шротов - такље концентрации валина, треонина и фенилаланина, а при скармливании подсолнечного жмыха - концентрации лейцина. Среди заменимых аминокислот в рубиее коров опытных групп при этом увеличивалось количество аспарагиновой кислоты, серина, аланина $(P<0,05-0,01)$.

В отличие от общзи аминокислот, концентрация свободных аминокислот в содержсмом рубца коров опытных групп была на 14,8-18,0\% меньше $(P<0,05)$, чем у коров контрольной группь, в основном вследствие уменьшения концентращии незаменимых аминокислот гистидина, метионина, лейцина. Из заменимых аминокислот при этом уменьшилась концентрация глутаминовой и аспарагиновой кислот, глицина, пролина, серина, тирозина $(P<0,05-0,01)$. Эти данные свидетельствуют об уменьшении деградациии незаменимых аминокислот в рубче и увеличение их поступления в кишечник и усвоения в организме.

Ключевые слова: КОРОВЫ, СОДЕРЖИМОЕ РУБЦА, АМИНОКИСЛОТЫ, РАПСОВЫЙ ШРОТ, СОЕВЫЙ ШРОТ, ПОДСОЛНЕЧНЫЙ ЖМЫХ, ЭКСТРУДИРОВАННЫЕ КОРМА, ЛАКТАЦИЯ

Introduction. Modern systems of cows protein nutrition are being based on the idea that their need of protein should provide, on one hand, microorganisms need of nitrogen (by means of easily degraded proteins and non-protein nitrogen compounds), and on the other hand - cows need in amino acids located in microbiological protein and undegradable in rumen proteins. Therefore, protein nutrition systems of cow that separately provide the need in degradable and undegradable in rumen proteins are developed in countries with advanced dairy cattle-breeding [1-7].

The nutrition system of protein in cows was accepted in Ukraine, which is based on rationing by content of raw and digestible protein $[8,9]$ without accounting for the need of degradable and undegradable proteins, might cause overuse of fodder proteins, smaller output and increase in price of production, metabolism and reproductive function disorders [10].

However, developed in other countries systems of protein nutrition of cows cannot be unconditionally implemented in Ukraine due to differences in fodder set, technologies of its preparation, preservation and preparation for feeding.

Our diets usually do not provide for consumption of needed amounts of undegradable in rumen proteins due to high level of degradability of high-protein fodder's proteins. Therefore, the problem of increasing the efficiency of using in cows feeding high-protein fodders by means of decreasing degradability of protein through extruding is important. Urgency in analyzing this problem was also caused by small amounts of raised and produced in Ukraine fodder with high levels of undegradable in rumen proteins. Therefore, our research was aiming to 
determine the influence of decreasing degradability of proteins from high-protein fodder through extruding on processes of forming the protein metabolites fund in highly productive cows during the initial stage of lactation.

\section{Materials and methods}

Three series of experiments were conducted. First experiment was carried out during the initial period of lactation on three cows of Ukrainian Black-and-White dairy breed. T-shaped fistulas were placed in their duodenums before pancreatic duct influx. Productivity of cows amounted to 3.5-4.0 thousand kilograms of milk over lactation period.

Rations assembled according to accepted standards [11, 12, 13] based on actual fodder nutritional value contained: meadow hay $(4 \mathrm{~kg})$, corn silage (25 kg), chopped wheat straw $(1 \mathrm{~kg})$, mangel-wurzel (14 kg), coarse bran (3 kg), rapeseed cake of Tysmenetskyi kind $(2.5 \mathrm{~kg})$, molasses $(0.5 \mathrm{~kg})$ and balancing vitamin and mineral supplement. During the preparation period cows were fed with extruded rapeseed meal, during the experimental period - extruded rapeseed meal, which caused the amount of undegradable in rumen raw protein of the diet to increase from 29.7 to $41.2 \%$.

Degradability of ration fodder proteins was determined by in situ method on bull-calves with rumen fistulas. To determine digestibility and input of fodder nutrients at the end of each experimental period, four-day balancing experiments were conducted. On the second and fourth day of each metabolism experiment, rumen contents were examined. The amount of total and free amino-acids was determined in rumen contents using amino-acid analyzers $A A A$ and $L C$ 2000 (Biotronic).

Second and third experiments were carried out on 10 intact cows of Ukrainian red-and-white dairy breed, divided into two groups according to binate analogue principle by 5 heads (control and experimental), during $1 / 3$ of lactation period. Productivity during the lactation period amounted to 5.7-6.6 thousand kilograms of milk.

During the second experiment, ration of control and experimental group consisted of $5.5 \mathrm{~kg}$ of meadow hay, $1 \mathrm{~kg}$ of chopped corn straw, $25 \mathrm{~kg}$ of corn silage, $16 \mathrm{~kg}$ of mangel-wurzel, $3 \mathrm{~kg}$ of coarse bran, $3 \mathrm{~kg}$ of soybean meal, $1 \mathrm{~kg}$ of molasses and vitamin and mineral supplement. Rations were composed based on determination of actual fodder nutritional value. Fed fodder protein degradability was established by the means of its incubation in the rumen of bull-claves with fistulas.

Cows of the control group were fed with non-extruded soybean meal, cows of the experimental group - with extruded soybean meal, which resulted in the increase in amount of undegradable in rumen protein in experimental group diet from 31.7 to $43.9 \%$.

During the third experiment, both groups ration consisted of meadow hay $(5.5 \mathrm{~kg})$, chopped wheat straw $(1 \mathrm{~kg})$, corn silage $(25 \mathrm{~kg})$, mangelwurzel (16 kg), coarse bran (3 kg), sunflower cake (3 kg), molasses ( $1 \mathrm{~kg})$, vitamin and mineral supplement. Cows of control group were fed with non-extruded sunflower cake, cows of experimental group - with extruded sunflower cake. This caused the amount of undegradable in rumen protein to increase from 28.5 to $39.5 \%$.

Rations were composed based on the zootechnical analysis of diet fodder and determination of their protein degradability by means of in situ method on bull-calves with rumen fistulas.

At the end of experimental period of the second and third experiments, four-day metabolism experiments were conducted to determine the digestibility and input of diet's nutrients. On the second and fourth day of each metabolism experiment, samples of rumen contents were taken with the help of a probe two hours after feeding.

The research we have conducted has determined that as a result of extruding protein degradability of rapeseed meal decreased from 70.0 to $46.6 \%$, or by $23.4 \%$; of soybean meal from 65.0 to $37.8 \%$, or by $27.2 \%$; of sunflower cake — from 72.5 to $46.4 \%$, or by $26.1 \%$.

\section{Results and discussions}

Data shown in Tables 1, 2 and 3 illustrates that amino-acids profile of rumen contents, in particular total and free amino acids profile, largely depends on the amount of undegradable 
Amino acids concentration in ruminal content of cows under the feeding up of rapeseed meal, $\mathrm{g}^{-3} / \mathbf{l},(\mathrm{M} \pm \mathbf{m}, \mathbf{n}=\mathbf{6})$

\begin{tabular}{|c|c|c|c|c|}
\hline \multirow{3}{*}{ Amino acids } & \multicolumn{4}{|c|}{ Research periods } \\
\hline & \multicolumn{2}{|c|}{ Preparation } & \multicolumn{2}{|c|}{ Experimental } \\
\hline & Total & Free & Total & Free \\
\hline \multicolumn{5}{|c|}{ Essential amino acids } \\
\hline Lysine & $221.3 \pm 12.9$ & $19.7 \pm 1.25$ & $291.0 \pm 14.1^{* *}$ & $20.1 \pm 1.14$ \\
\hline Histidine & $106.2 \pm 6.35$ & $9.5 \pm 0.73$ & $97.0 \pm 5.73$ & $6.7 \pm 0.65^{*}$ \\
\hline Arginine & $194.8 \pm 8.17$ & $17.3 \pm 1.09$ & $223.1 \pm 9.49 *$ & $13.4 \pm 0.98^{*}$ \\
\hline Threonine & $216.9 \pm 10.43$ & $19.3 \pm 1.32$ & $257.1 \pm 12.33^{*}$ & $17.7 \pm 1.22$ \\
\hline Valine & $212.5 \pm 11.44$ & $18.9 \pm 1.08$ & $291.0 \pm 16.03 * *$ & $16.9 \pm 1.31$ \\
\hline Methionine & $97.4 \pm 4.98$ & $8.7 \pm 0.41$ & $126.1 \pm 7.25 * *$ & $7.3 \pm 0.36^{*}$ \\
\hline Isoleucine & $190.4 \pm 5.87$ & $16.9 \pm 1.11$ & $218.3 \pm 8.56^{* *}$ & $15.0 \pm 0.99$ \\
\hline Leucine & $433.8 \pm 19.18$ & $38.6 \pm 1.95$ & $422.0 \pm 15.25$ & $32.5 \pm 1.09^{*}$ \\
\hline Phenylalanine & $208.1 \pm 9.45$ & $18.5 \pm 1.23$ & $252.2 \pm 11.61^{*}$ & $17.4 \pm 1.15$ \\
\hline Total essential amino-acids & $1881.4 \pm 49.5$ & $167.4 \pm 6.09$ & $2158.4 \pm 63.43 * *$ & $147.0 \pm 5.41 *$ \\
\hline \multicolumn{5}{|c|}{ Nonessential amino acids } \\
\hline Asparaginic acid & $448.4 \pm 27.21$ & $35.5 \pm 2.25$ & $611.6 \pm 33.51 * *$ & $30.9 \pm 2.08$ \\
\hline Serine & $220.3 \pm 11.45$ & $19.7 \pm 1.33$ & $247.4 \pm 13.28$ & $17.0 \pm 1.24$ \\
\hline Glutaminic acid & $726.0 \pm 39.57$ & $64.5 \pm 3.45$ & $795.5 \pm 42.83$ & $52.8 \pm 2.39 *$ \\
\hline Proline & $270.0 \pm 7.39$ & $31.1 \pm 2.12$ & $232.8 \pm 9.68 * *$ & $23.6 \pm 1.75^{*}$ \\
\hline Glycine & $272.2 \pm 16.04$ & $26.0 \pm 1.49$ & $243.9 \pm 12.59$ & $22.1 \pm 1.18$ \\
\hline Alanine & $339.6 \pm 19.03$ & $34.7 \pm 1.88$ & $295.8 \pm 16.32$ & $29.4 \pm 1.81$ \\
\hline Cyctine & $74.3 \pm 3.68$ & $3.9 \pm 0.32$ & $97.6 \pm 5.15 * *$ & $3.3 \pm 0.29$ \\
\hline Tyrosine & $199.2 \pm 5.47$ & $17.7 \pm 1.44$ & $218.3 \pm 6.09$ & $15.0 \pm 1.03$ \\
\hline Total nonessential amino-acids & $2541.0 \pm 94.23$ & $233.1 \pm 11.14$ & $2696.8 \pm 98.74$ & $194.1 \pm 9.71$ \\
\hline
\end{tabular}

Note. In this and further tables: * - the degree of probability of differences in terms of relative control; * $\mathrm{P}<0.05 ; * *-\mathrm{P}<0.01 ; * * *-\mathrm{P}<0.001$

Table 2

Amino-acids concentration in ruminal content of cows under the feeding up of soybean meal, $\mathrm{g}^{-3} / \mathbf{l},(\mathrm{M} \pm \mathbf{m}, \mathbf{n}=\mathbf{5})$

\begin{tabular}{|c|c|c|c|c|}
\hline \multirow{3}{*}{ Amino acids } & \multicolumn{4}{|c|}{ Groups } \\
\hline & \multicolumn{2}{|c|}{ Control } & \multicolumn{2}{|c|}{ Experimental } \\
\hline & Total & Free & Total & Free \\
\hline \multicolumn{5}{|c|}{ Essential amino acids } \\
\hline Lysine & $303.1 \pm 2.43$ & $28.2 \pm 2.17$ & $350.8 \pm 14.05^{*}$ & $24.6 \pm 1.67$ \\
\hline Histidine & $99.4 \pm 4.78$ & $9.3 \pm 0.65$ & $98.7 \pm 5.03$ & $6.9 \pm 0.58 *$ \\
\hline Arginine & $243.5 \pm 2.23$ & $22.7 \pm 0.98$ & $290.5 \pm 4.83 * * *$ & $20.4 \pm 1.03$ \\
\hline Threonine & $218.4 \pm 9.03$ & $24.1 \pm 1.21$ & $254.9 \pm 11.15^{*}$ & $21.2 \pm 1.07$ \\
\hline Valine & $293.2 \pm 16.29$ & $27.3 \pm 1.66$ & $372.8 \pm 21.48^{*}$ & $26.2 \pm 1.43$ \\
\hline Methionine & $84.3 \pm 5.07$ & $9.7 \pm 0.61$ & $109.6 \pm 6.98^{*}$ & $7.7 \pm 0.54 *$ \\
\hline Isoleucine & $233.5 \pm 10.48$ & $21.8 \pm 1.17$ & $246.7 \pm 12.09$ & $17.3 \pm 0.58 * *$ \\
\hline Leucine & $482.3 \pm 29.45$ & $40.3 \pm 2.27$ & $470.7 \pm 24.93$ & $29.6 \pm 1.78 * *$ \\
\hline Phenylalanine & $268.3 \pm 14.21$ & $25.0 \pm 1.24$ & $317.9 \pm 15.09^{*}$ & $22.3 \pm 1.33$ \\
\hline Total essential amino-acids & $2236.0 \pm 61.76$ & $208.4 \pm 8.25$ & $2510.6 \pm 88.35^{*}$ & $176.2 \pm 6.43 *$ \\
\hline \multicolumn{5}{|c|}{ Nonessential amino acids } \\
\hline Asparaginic acid & $576.4 \pm 29.79$ & $53.7 \pm 2.07$ & $592.0 \pm 37.58$ & $41.6 \pm 2.54 * *$ \\
\hline Serine & $253.4 \pm 12.89$ & $23.6 \pm 1.29$ & $268.6 \pm 14.09$ & $18.9 \pm 1.03 *$ \\
\hline Glutaminic acid & $805.0 \pm 47.38$ & $75.0 \pm 4.25$ & $882.6 \pm 52.95$ & $62.0 \pm 3.28 *$ \\
\hline Proline & $208.7 \pm 7.28$ & $19.4 \pm 1.23$ & $246.7 \pm 12.08^{*}$ & $17.3 \pm 0.99$ \\
\hline Glycine & $263.4 \pm 13.07$ & $24.5 \pm 1.34$ & $268.6 \pm 14.25$ & $18.9 \pm 0.9 * *$ \\
\hline Alanine & $342.9 \pm 12.98$ & 31.92 .05 & $389.2 \pm 15.07^{*}$ & $27.3 \pm 1.78$ \\
\hline Cyctine & $54.7 \pm 2.07$ & $5.1 \pm 0.66$ & $65.8 \pm 4.21 *$ & $4.6 \pm 0.48$ \\
\hline Tyrosine & $228.6 \pm 8.75$ & $23.6 \pm 1.28$ & $257.6 \pm 11.37$ & $18.1 \pm 0.93 * * *$ \\
\hline Total nonessential amino-acids & $2733.1 \pm 63.25$ & $256.8 \pm 10.85$ & $2971.0 \pm 78.36^{*}$ & $208.7 \pm 8.89 * *$ \\
\hline Asparaginic acid & $4923.4 \pm 137.81$ & $465.2 \pm 19.95$ & $5443.7 \pm 146.34 *$ & $384.9 \pm 25.23 *$ \\
\hline
\end{tabular}


Amino acids concentration in ruminal content of cows under the feeding up of sunflower cake, $\mathrm{g}^{-3} / \mathbf{l},(\mathrm{M} \pm \mathbf{m}, \mathbf{n}=\mathbf{5})$

\begin{tabular}{|c|c|c|c|c|}
\hline \multirow{3}{*}{ Amino acids } & \multicolumn{4}{|c|}{ Groups } \\
\hline & \multicolumn{2}{|c|}{ Control } & \multicolumn{2}{|c|}{ Experimental } \\
\hline & Total & Free & Total & Free \\
\hline \multicolumn{5}{|c|}{ Essential amino acids } \\
\hline Lysine & $192.2 \pm 13.90$ & $17.2 \pm 1.05$ & $237.9 \pm 12.59^{*}$ & $16.3 \pm 1.13$ \\
\hline Histidine & $163.3 \pm 8.77$ & $13.6 \pm 0.87$ & $153.3 \pm 12.23$ & $10.3 \pm 0.97^{*}$ \\
\hline Arginine & $216.2 \pm 9.28$ & $22.6 \pm 4.67$ & $248.5 \pm 10.44 *$ & $20.1 \pm 2.33$ \\
\hline Threonine & $278.6 \pm 12.23$ & $24.9 \pm 3.70$ & $296.1 \pm 16.10$ & $22.0 \pm 2.40$ \\
\hline Valine & $206.6 \pm 12.44$ & $24.0 \pm 1.15$ & $227.4 \pm 15.73$ & $20.9 \pm 1.61$ \\
\hline Methionine & $96.1 \pm 5.63$ & $8.6 \pm 0.20$ & $116.3 \pm 6.14^{*}$ & $8.0 \pm 0.16$ \\
\hline Isoleucine & $201.8 \pm 5.27$ & $19.9 \pm 1.15$ & $211.5 \pm 5.04$ & $17.5 \pm 1.29$ \\
\hline Leucine & $485.2 \pm 14.0$ & $41.2 \pm 2.01$ & $544.7 \pm 21.0^{*}$ & $33.1 \pm 2.42 *$ \\
\hline Phenylalanine & $197.0 \pm 3.08$ & $20.8 \pm 0.98$ & $211.5 \pm 3.46$ & $18.6 \pm 0.76$ \\
\hline Total essential amino-acids & $2037.0 \pm 57.8$ & $192.8 \pm 6.92$ & $2247.2 \pm 69.10^{*}$ & $166.8 \pm 5.39$ \\
\hline \multicolumn{5}{|c|}{ Nonessential amino acids } \\
\hline Asparaginic acid & $451.6 \pm 10.02$ & $52.1 \pm 2.53$ & $502.4 \pm 18.01$ & $39.9 \pm 3.96^{*}$ \\
\hline Serine & $245.0 \pm 9.37$ & $23.6 \pm 1.23$ & $280.3 \pm 12.15^{*}$ & $18.25 \pm 1.89^{*}$ \\
\hline Glutaminic acid & $807.1 \pm 27.1$ & $76.6 \pm 3.03$ & $877.8 \pm 39.09$ & $62.0 \pm 4.11 *$ \\
\hline Proline & $235.4 \pm 10.05$ & $16.3 \pm 0.98$ & $280.3 \pm 11.10^{*}$ & $14.8 \pm 1.29$ \\
\hline Glycine & $345.9 \pm 26.2$ & $30.8 \pm 1.68$ & $359.6 \pm 28.10$ & $24.3 \pm 2.21 *$ \\
\hline Alanine & $437.2 \pm 12.98$ & $38.1 \pm 4.9$ & $481.2 \pm 13.41^{*}$ & $33.1 \pm 3.88$ \\
\hline Cyctine & $48.0 \pm 2.74$ & $5.4 \pm 0.54$ & $58.2 \pm 3.07 *$ & $5.3 \pm 0.39$ \\
\hline Tyrosine & $197.0 \pm 3.87$ & $17.7 \pm 2.03$ & $211.5 \pm 6.34$ & $15.6 \pm 1.98$ \\
\hline Total nonessential amino-acids & $2767.2 \pm 79.49$ & $260.6 \pm 11.93$ & $3051.3 \pm 87.32 *$ & $213.3 \pm 8.49^{*}$ \\
\hline Asparaginic acid & $4804.2 \pm 137.08$ & $463.4 \pm 15.18$ & $5298.5 \pm 146.28^{*}$ & $380.1 \pm 24.12^{*}$ \\
\hline
\end{tabular}

in rumen proteins in their diet. This statement is suggested by the considerable differences in amino acid make-up of ruminal content of cows under the feeding up of extruded fodder.

Greater amount of total amino-acids and smaller amount of free amino-acids in ruminal content of cows the feeding up of extruded rapeseed meal, soybean meal and sunflower cake are common for all experiments.

During all experiments, among total amino-acids, the increase of lysine, arginine, methionine, proline and cyctine concentration in rumen contents of cows, that were fed with extruded fodder, took place $(\mathrm{P}<0.05-0.01)$. Moreover, the increase of valine, threonine, isoleucine, phenylalanine and asparaginic acid in ruminal contents of cows took place while the feeding up of rapeseed meal $(\mathrm{P}<0.05-0.01)$. While using extruded soybean meal in cows' ration the level of valine, threonine, phenylalanine and alanine in cows' rumen contents was increasing $(\mathrm{P}<0.05)$. While feeding cows with sunflower cake concentration of leucine, serine and alanine in rumen content was increasing as well.
Overall, total amount of amino acids in ruminal content of cows was increasing under the feeding up of the rapeseed meal, soybean meal and sunflower cake by $9.8,10.6$ and $10.3 \%$ $(\mathrm{P}<0.05)$ respectively. These differences are determined by higher concentration of essential amino acids, the amount of which in rumen content of cows of experimental groups was higher by $14.7,12.3$ and $10.3 \%(\mathrm{P}<0.05-0.01)$. Such differences in amino acid concentration in rumen content of cows of experimental groups are determined by the decrease of proteolysis of extruded supplements proteins and amino acids degradability.

Feeding up cows with extruded rapeseed meal, soybean meal and sunflower cake has also influenced the concentration of free amino acids in rumen content. Particularly, while feeding cows with rapeseed meal (Table 1), among free essential amino acids, lower concentration of histidine, arginine, methionine, leucine was established $(\mathrm{P}<0.05)$ compared to cows that were fed with non-extruded rapeseed meal. Among nonessential amino acids in ruminal content 
of cows, less glutaminic acid and proline was found during the research period $(\mathrm{P}<0.05)$.

It was determined (Table 2) that while feeding up cows with extruded soybean meal in their rumen content, among free essential amino acids, less histidine, methionine, isoleucine and leucine was found $(\mathrm{P}<0.05-0.01)$, among nonessential amino-acids - less asparaginic and glutaminic acids, serine, glycocoll and tyrosine $(\mathrm{P}<0.05-0.001)$.

Cows which were fed with extruded sunflower cake have demonstrated that in their rumen content there were less free essential amino acids - histidine and leucine $(\mathrm{P}<0.05)$, compared to rumen content of cows that were fed with nonextruded sunflower cake (Table 3). At the same time, in nonessential amino acids profile, smaller amounts of asparaginic and glutaminic acids, serine and glycine were found $(\mathrm{P}<0.05)$.

It should be noted that the concentration of practically all free amino acids in rumen content was decreasing while feeding up cows with extruded protein supplements, although this was not always statistically reliable. As the result, their level has decreased in the experiment with rapeseed meal by $14.8 \%(\mathrm{P}<0.05)$, with soybean meal - by $17.3 \%(\mathrm{P}<0.05)$, with sunflower cake - by $18.0 \%(\mathrm{P}<0.05)$. Like in the case of total amino acids, to the greater extent this applies to essential amino-acids.

\section{Conclusions}

Feeding cows with extruded high-protein fodder leads to the increase of amount of total amino-acids in rumen content, especially of essential amino acids - lysine, arginine and methionine $(\mathrm{P}<0.05-0.01)$. While feeding up cows with extruded rapeseed and soybean meal amount of valine, threonine and phenylalanine increases as well, while feeding with sunflower cake - amount of leucine increases. Concentration of free amino acids decreases, mostly due to the decrease in concentration of essential aminoacids of histidine, methionine and leucine.
Perspectives for further research. Further research should be carried using out to determine methods of increasing the efficiency of fodder proteins for milk synthesis.

1. Tsyupko V. V., Zlobina G. S., Vasilevskiy M. V. Rationing protein feeding cattle. Stock-raising of Ukraine, 1996, 10, pp. 26-27. (in Ukrainian)

2. Dinn N. E., Shelford J. A., Fisher L. J. Use of Cornell net carbohydrate and protein system and rumen-protected lysine and methionine to reduce nitrogen excretion from lactating dairy cows. Journal of Dairy Science, 1998, 81, pp. 229-237.

3. Huhtanen P. A review of the 2001 dairy cattle NRC protein and amino acid model - A European perspective. Journal of Dairy Science, 2005, 88, pp. 107-130.

4. INRA. Ruminant nutrition. Recommended allowances and feed tables. R. Jarrige, ed. John Libbey Eurotext, London, Paris, 1989.

5. Nutrient Requirements of Dairy Cattle: Sixth Revised Edition.Washington, DC, USA: National Academy Press, 1989, 168 p.

6. Nutrient Requirements of Dairy Cattle: Seventh Revised Edition. Washington, DC, USA: National Academy Press, 2001, 408 p.

7. Metcalf J. A., Wray-Cahen D., Chettle E. E., Sutton J.D., Beever D. E., Crompton L.A., MacRae J. C., Bequette B. J., Backwell F. R. The effect of dietary crude protein asprotected soybean meal on mammary metabolism in the lactating dairy cow. Journal of Dairy Science, 1996, 79, pp. 603-611.

8. Aliev A.A.Lipid exchange and productivity of ruminant zoons. Moscow, Kolos, 1980, 382 p. (in Russian)

9. Grigorev N. G, Volkov N. P, Vorobev E. S. Biological full value of forage. Moscow, Agropromizdat. 1989, 287 p. (in Russian)

10. Vantuh A. E. Milk performance and the level of some metabolities in blood and rumen liquid of cows using soybean and canola meal in ration. Avtoref. cand. agr. sci. diss. Lviv, Institute of animal biology NAAS, 2003, 22 p. (in Ukrainian)

11. Norms and rations of feeding of agricultural zoons. Handbook edited A. P. Kalashnikov. Moscow, Agropromizdat, 1985, 352 p. (in Russian)

12. Norms and rations of feeding of agricultural zoons. Handbook. Ch. 1. Cattle. Edited A. P. Kalashnikova. Moscow, Znanie, 1995, 400 p. (in Russian)

13. Norms and rations of feeding of agricultural zoons. Handbook. 3 editions of redesigned and enlarged, edited A. P. Kalashnikov. Moscow, 2003. 456 p. (in Russian) 